\title{
In Search of New Identity for LIS Discipline, with Some References to Iran
}

\author{
Gholamreza Fadaie \\ Faculty of Psychology \& Education, University of Tehran, Iran
}

\author{
ghfadaie@ut.ac.ir
}

\begin{abstract}
The present paper offers that most of the advocates of discipline of library and information science believe that there is a lack of theoretical foundation and rational identity. The author maintains that there has been an error in defining the subject by confusing library with librarianship. That is many researchers have derived the concept of librarianship from library. Therefore they came to define librarianship as an entity only through the social application and services. If instead, a librarian was assumed to be a person who was usually a scholar, with or without the knowledge of classification properly, and if it was further assumed that before establishing any library, at least there has always been one thoughtful person with the enthusiasm of classifying his own tacit or explicit knowledge in order to retrieve, the concept of librarianship could have been derived from the concept of personal seeking of knowledge, or the need of any knowledgeable person who believes in scientific classification for the sake of retrieval. Thus, there has always been the necessity for scientific classification even if there has not been any formal library. So, I propose that librarianship is more related to the knowledge retrieval and classification which is in the mind of all people specially scholars and learned men before the library, as a place for the collection of books and other materials come to being.
\end{abstract}

Keywords: Library, Librarianship, Information science, Information studies, Meta science, Theoretical foundation, Classification, Retrieval.

\section{Introduction}

Nowadays the library and information sciences (LIS) have reached to its highest degree of attention and I think it is mostly due to the electronic development. By electronic development which is presented through internet and intranet activities one may consider that it is the librarianship which has got its real place. But one may argue that technology and especially information technology has affected on many disciplines and subjects. It is much better to say that this discipline has got the best benefit from technology development due to its nature that is information, documents, books, and knowledge. Nevertheless changes have been made by technology do not

Material published as part of this publication, either on-line or in print, is copyrighted by the Informing Science Institute. Permission to make digital or paper copy of part or all of these works for personal or classroom use is granted without fee provided that the copies are not made or distributed for profit or commercial advantage AND that copies 1) bear this notice in full and 2) give the full citation on the first page. It is permissible to abstract these works so long as credit is given. To copy in all other cases or to republish or to post on a server or to redistribute to lists requires specific permission and payment of a fee. Contact Publisher@InformingScience.org to request redistribution permission. change the nature of any discipline.

Every discipline and field of study must have its theoretical or philosophical foundation first, and then it can certainly be more manifested and used by technology.

Librarianship and then information science, although are very important and widely used every where and in any time suffers from a theoretical basis in comparison with other disciplines. Few 
people such as Patrick Wilson opened the horizon of philosophical tendency in LIS (Hjorland, 2005, p. 5). Belkin, Ingewerson, Ellis, Ervin and others try to search some cognitive foundations for LIS through information seeking (Budd, 2001, pp. 256-257). They are all against positivist scholars in this domain. Bakhtin, too by describing information seeking looks at LIS from communication and phenomenology point of view. These days there are a lot of debates and controversial discussion among the rhetoricians who try to find a valuable basis for them. They try to find a basis for library sciences as well for information studies (Ebrami, 1379/1999, pp. 22, 17).

Although LIS discipline is considered as interdisciplinary area there must be some concrete definition for it as well.

\section{Questions Facing Library and Information Science}

This article is tying to answer some questions as follows: Is librarian the best designation for the specialists in this domain? Are famous librarians or information specialists satisfied with the lack or uncompleted definition for the subject? Are there any theoretical shortcomings for this field? Does this discipline challenge with other subject specialists such as computer men, information specialists, specialists in communication and so on? Is it possible to change the name or define to a better definition befitting the functions of the librarians? Is the Information specialist the best partner for the librarian in this age? As I had mentioned earlier librarianship, especially in Iran, suffers from a number of problems which may be classified as follows:

\section{Name and Naming}

Name and designations are very important for people in their lives. By choosing the appropriate name good communication takes place. Therefore more attention should be paid in designating abstract terms for subjects and disciplines. Librarianship as a discipline may suffer from such mis-designation especially in some nations. By this designation some think that the task of librarian is only to keep the books and other materials and /or lend them to the users. Some problems that may arise from designation are that the concept of librarianship derives from the library as a surrounded place.

\section{Lack of Clear Identity}

Some professions are self- defining; in some others the job occupiers may define them. The librarianship may be not so at least at first glance. They call him librarian not because what he does such as farmers, and he is not like lawyers either who are engaged with laws. But $\mathrm{s} /$ he is famous because of the place he works in. The definitions for librarian although is clear, in explaining the ability of the librarian is silent (Christ, 1986 /1365).

Many people think that the librarian is a book keeper and its aim is to preserve the books in a place called library or at most to lend the materials when asked for. It is also said that the librarianship is a social activity. Its aim is to satisfy the users. The librarian, some believe, is regarded and compared as a book vendor, whose aim is to sell more and attract the users' attention. In this context there is a serving definition for it. So there is no basic attribute for the discipline except the user's view. It is actually a service oriented job and subordinate to what the people want and is not independent.

With the emergence of new information technology and Internet, the situation has changed notably. But before using internet in the libraries, in some countries such as Iran, one used to hide his profession in a way. In Iran, if somebody wanted to be employed, his main challenge with the employers was to define what exactly the field was. This problem not only arose during job interviews, but also after getting the job, since most often the librarian did not know how to deal with 
himself rather than others. For a new librarian, it was not anything more problematic than to find in what profession s/he enters.

\section{Library and Librarianship}

It is true that without any library as a building, there might not be librarianship as a profession or

discipline or at least the kind we know now. But, is it accurate to define librarianship as discipline from library functions? This is also pretty much true for the definition of information sciences. Unfortunately, many subject specialists have defined librarianship in the context of library. For example, Mukuhreje (1999), in defining the librarianship, states: "The library has two functions: one is education and the other is recreation". One may find in his definition that the first function is exaggerated, and the latter is rather non academic. Another definition maintains the library to be a sub social institution having a tendency to satisfy users and provide them with documents they need. This definition lacks theoretical basis and may not bring any prestige for the librarians. Nitecki's definition (Christ, 1986) may have some more idea that says:

First, library is for user services, but its social respect should be clarified in such a way to provide the users with thought rather to be a passive collection of books.

Even Ranganathan, as a famous librarian, defines the librarianship through the library services. His five famous rules support this idea. I believe that trying to define librarianship by library is akin to defining pharmacology by pharmacy.

\section{Lack of Clear Theory for LIS}

To stay vital and vibrant, every subject or discipline has to have a fundamental theory. This theory must originate from the basic needs of human beings. In spite of its myriad of definitions, librarianship as a science, suffers from the lack of a viable theory. Its fortune has waned and ranked lower relative to some pure service-oriented jobs. The lack of a theoretical basis for LIS created big problems on the way for library education (Christ, 1986). Christ stated that the most of what a student of library science learns could be passed off as some vague and ordinary statement for practical functions. In fact, to remain viable and progressive, a discipline should be backed up by a powerful theoretical framework. He says:

Epistemology, as a branch of philosophy is necessary for all disciplines, especially for academic ones. The librarianship has not paid attention to this.

One may think that the information science is something else and differs from librarianship and it has attained its own theoretical basis and is of high rank in comparison with librarianship. Even though the American Society of Information Sciences called it as a science and tried to search an identity for information science, still it suffers from a defining theory. Shera states that there are about 700 definitions for information science and this brings confusion (Hjorland, 2002). Thus, the information science as a new discipline suffers from the lack of definition focus too (Ellis, Allen. \& Wilson, 2002).

\section{Vague Relationship between Librarianship and Information Science}

Some may try to demonstrate the information science as a legitimate outcome of librarianship. At least some place librarianship and information science at both ends of a spectrum. I was one of the advocates of the latter (Fadaie, 2004a). But I think there is a lack of linkage here. In fact, there should be some reasons to do so. What one muses about librarianship, at first glance, is stillness and rigidity, just like books on the shelves. But what comes into the mind from information sci- 
ence as the result of technological age may be movement, speed and accurateness. In fact, information science is innovation driven.

If one argues that the information science has appeared as the result of extension of library information quantitatively and qualitatively, the answer is: Although inside the libraries and within the books and other documents there is a lot of information stored and must be brought out through good indexing, still the information is so wide and vast that cannot be confined to the library as a building. The information is found everywhere and can be collected and stored in any place. In fact, the information is so vast and absolute that it does not belong to one discipline. It is mixed with everything and covers all the life. Without information nothing is meaningful. Thus, some may argue that although information technology has affected everything, including librarianship, it is not correct to allocate it exclusively to librarianship.

\section{Social Application}

The social application of the library emerged and enforced following the inception and rapid development of the libraries especially Library of Congress. The managers in the Library of Congress were engaged in classification and organization of the collections in whatever way possible. Therefore, they did not, or could not care about a theoretical basis for their classification. The social, political and financial support of the library established and fostered the notion of the library as a social institute and librarianship as the science of applying the library. Its function was described as nothing more than to classify the materials in a way to serve the users properly. This although sounds great it does not convey a meaningful and theoretical basis for the subject. Recently there have been changes in library conception especially in academic one. For example Yoder (2003, p. 380) calls it as "supreme form of rational social organization".

\section{Changing the Title of Schools of Library Sciences}

In the aftermath of technology-driven information explosion of mid - 80's, some library schools hastened to omit the name of library from their titles. They came to this idea that in the age of rapid information transferring and diffusion there is no need for library science as a discipline or library as a place. There may be some exceptions for the undeveloped areas. Denis Lewis, subsequently director of ASLIB, pessimistically forecast a doomsday scenario where libraries as we know them disappear (Wilson, 2002). Besides of the United States of America and Canada, some countries such as Thailand, and South Africa did so. Some of the schools changed the syllabus in their courses in favor of information science rapidly.

\section{Librarians do not Usually Administer the Libraries}

This may not be considered as a major problem and may not be totally true in Western countries, but it is a fact in some countries such as Iran. The top managers, even in universities thought and still think that the librarianship was something for preparation of the documents in the backrooms of the libraries. Since last decade few librarians' bids for becoming a member of faculty went unchallenged in the universities.

\section{Why Has This Happened?}

Because of the above-mentioned notions, situations have been in such a way that the librarians might feel some inferiority in their professional lives. Because there was and still is no theoretical basis for LIS, there is no means for librarians to defend their academic and social status. They think that for promotion of their professional status, they have to borrow some concepts or principles from other disciplines such as computer science and communication (Budd, 1998; 2001, p. 259). On the other hand, many computer specialists work on classification and indexing indicat- 
ing the increasing need for information processing and retrieval in its special concept as it is treated in librarianship. Indexing, with the three functions of condensing the information in a document, providing a bridge between the author and the researcher, and as an instrument that govern search strategy (Bloomfield, 2001) still offers the only way for the successful retrieval. Some information technologists from electronic field do their best in retrieval processing (Hyneck, 2002). But as far as they are not so familiar with indexing, they are not successful in their job.

I believe that although the LIS are important and the librarian may be satisfied with his job, still there is a lack of theory which impedes it from standing tall along with other disciplines.

The problem, I suppose, is due to the fact that the idea of librarianship is derived from library, while the library is created by human needs for retrieval. In other words library as a place has not anything to build theoretical foundation for librarianship as a discipline. This is the reason that up to now in defining the theoretical foundation of librarianship the authors mostly describe the history of the libraries or try to define the social needs for information. Even information seeking defined by Bakhtin and others emphasize on communication and dialogic conception (Budd, 2001, pp. 259-260). So I think that it is not true to indicate that the library as a place of books and other materials has forced people to search for classification and retrieval (Fadaie, 2004a). There is something more intrinsic in this discipline which comes out from human needs for information. Let's explain this further. Suppose there is no library as a building, is it correct to assume that every thoughtful person must organize his tacit or explicit knowledge? That is, it is true that before the industrial age there have been libraries in all over the world. It is true that during the industrial revolution in Western countries they expanded rapidly and led to the vast collection of books and other documents. But it is true that the idea of classification for retrieval has been at the center of every body's mind. This is why I believe that defining the discipline was made on the wrong foot. After the industrial age and emergence of big library collections, such as Library of Congress (LC), they hastily looked for some one to serve users through managing the collection in anyway possible. The LC cataloging code created and expanded along with the expansion of the collections without any philosophical underpinnings. Therefore, to them, serving others appeared to be the foundation of this new job in the industrial age. The growth of technology along with the growth of publications did not allow the scholars especially as librarians to think about theoretical basis for their profession. The growth of the information technology and services and the appearance of some reluctance towards librarianship caused the rethinking over the discipline by some scholars and subject specialists. Now we see many scholars in librarianship search for a theory and try to go beyond the so-called library science as a social function and activity. First, they sought their basic theoretical foundation in information technology and services. But after the failure of receiving any sufficient answer, now, they are trying to seek the fundamental basis in knowledge philosophy and management. For more explanation and to get new idea about the entity of librarianship, one must take into consideration several points as follows:

\section{Epistemological Approach in LIS}

One must think of, and take into one's consideration the man's epistemological procedure. If we consider this procedure we may find the role of LIS concept from the very beginning of man's epistemology. Hjorland $(2005,7)$ in his article LIS and the philosophy of science tries to define it systematically. His statement is:

The special aim of the present issue is the attempt to relate issues in LIS more systematically to major philosophical movements from outside. It may well be the most systematic attempt made so far to present and discuss basic epistemological issues in LIS. 
In the world of reality one sees or touches everything. That is in the realm of ontology every thing is in-form. But when it comes to mind or in the realm of epistemology you can never call it except putting in form, too. And you cannot put it in form unless you put it in group or class it in such a way you can retrieve it. Consider that if one thing is absolutely unique, you cannot define it and it is out of mental access. There fore it is evident that man's need for retrieval has led him to locate whatever he has thought or learned in his mind or any other places. Therefore, from the very beginning of the learning process when one encounters things, in remembering them one must have put them in the right places by good categorization or classification. It is a matter of negligence if many do not care about it. Ellis, Allen, and Wilson (2002) state that in building theory for information science they have not much spoken about human's information need. Here I would like to mention that this idea may be much stronger than the idea of information seeking introduced by Bakhtin (Budd, 2001). Because information seeking refers to users and may imply the seeking for information that is not clear enough for the seeker and the answerer, but here information retrieval implies that there has been information first and we have put it somewhere and now we (or others) by means of classification / indexing want to retrieve it (I will explain the differences between information seeking and information retrieval as theoretical basis for LIS in separate article). Here we produce the information and we put it some where in order to retrieve it because we need it in a way. In fact it is the story of memory and remembrance. That is we memorize to remember. Some may object that retrieval has attained its significance only during the information age. It is true, but I think it does not change the intrinsic importance of the retrieval process.

One may consider this issue from another angle. That is, Human Beings (HB) naturally needs information (IN) which have been produced by some one before and one knows that it is stored (by classification / indexing) somewhere. S/he seeks information (SI) either by self experience (SE), or by asking from a source. This source may be a special classified one (SCS) such as a knowledgeable man or any document, like a reference book. When information increases in quality, quantity, and form of access they are collected in a place such as library. That is library or any other reference source is a place for special classified sources (SCSS) as a mean which is established to facilitate man's access to his original need for information. Figure 1 may explain more

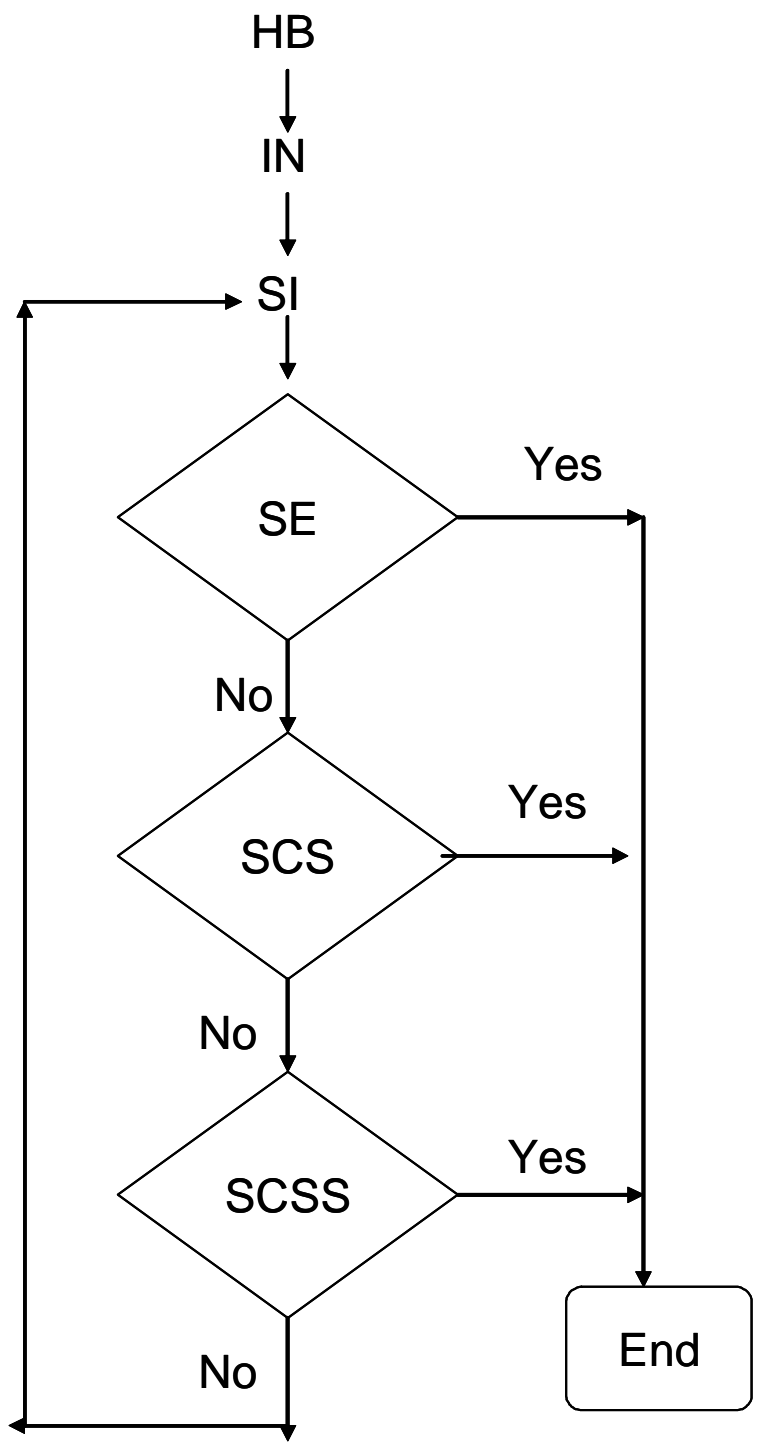

Figure 1.The process of seeking knowledge from various classified sources 


\section{Classification is for Retrieval}

Moreover, a scholar or a scientist has to classify his knowledge as well as any ordinary man who has to systemize and categorize his work. For example, if somebody needs something to use it for any ordinary purpose it is like when he wants to make a speech, write a paper, or make a book he has to arrange them in a systematic way in order to be able to refer, or to retrieve the ideas. The pagination and table of contents is the result of this notion.

\section{The Beginning of the Library}

When the volume of scientific papers or books increased, the main idea was to make a library, personal or public. One may observe that the first libraries have been personal for some individuals, such as kings and emperors and designated scholars. Therefore, the idea of classification as a way to facilitate the retrieval is the foundation of a discipline which now it is called librarianship. In fact, the library has appeared in support of this notion. Retrieval encourages us to organize knowledge. That is, if knowledge is well organized it will be well retrieved, too. So, we practice it in our individual lives by collecting, arranging and putting our necessary commodities somewhere in such a way that we can find them whenever or wherever we want to use them. Therefore, what is no longer of use we throw it away into the waste - basket. So for information retrieval and even in the Internet age the idea of database classification or organization is strong. As Losee (1990) states:

Information retrieval is the science of extracting from a database or network of organized [classified] information those items that satisfy a specific need.

\section{Librarian is a Scholar}

Another fact which one must take into one's consideration is that in most historical libraries, especially in Islamic countries, the real librarians have been scholars, or we can say that the real scholars have been the library managers. That is, scholars and learned people have been the main persons who had the idea of systematic classification for the sake of retrieval. It means that before finding the librarianship as a profession, there have been some scholars to think about how to classify their subject matters to retrieve. This may be what Thompson (1977) declares as one of his 17 principles for librarianship that a librarian must be a scientist or knowledgeable person.

\section{Knowledge Attribution}

After the information breakthrough, some scholars changed their mind and said the library is almost at the end of its utility and they must look at it as historical phenomena. Recently many librarians focused on the role of knowledge as the basis for librarianship. That is the classification is not originally related to the libraries, it is related to the knowledge itself. Reingeluth (n.d., p. 1) says: the nature of knowledge is nothing but classification and this classification is either for things or for their changes. Kawsnik (1999) stated that the real definition was possible just through hierarchical classification. She added:

There are many ways in which classification schemes and knowledge interact. Sometimes the interaction is so harmonious that the two remain linked for a long time. Some times knowledge changes and the classification must also change or knowledge changes and classification is no longer adequate to the task.

Other researchers (Muller, n.d., p. 1) believe that the class is the description of a set of objects that share the same attributes, operations, methods, relationships and semantics. Houser \& Schrader state (Budd, 2002) that the knowledge is unique and the librarianship and information 
science should be a part of it. Others (Hjorlnd \& Alberchtsen, 2002), by stating the special domain knowledge, have opened an approach to the knowledge. They mean that the organization of knowledge is to decide what the book is about or what information belongs to a specific subject domain. Therefore, the classification exists or must be applied wherever knowledge/information is going to be retrieved. Scientific collections such as those found in libraries are one of the examples. Thus it is not correct to say that a library is a place where there are a lot of books in it. Rather it must be said that the library is a place where the classified knowledge/ information could be found through books and other materials contained therein. So, the notion of scientific classification for retrieval precedes the library as a building. Maltby expresses an interesting thought (Miska, 1992) and says: "The foundation of the library is book; the foundation of librarianship is classification". But, I think it would have been much better if he stated that the foundation of library is classified knowledge storage and the foundation of librarianship is retrieval. In fact retrieval has been a key element of knowledge representation in all ages, from the earliest times that information was found. Of course, it is true that retrieval in the age of information infusion has attained its highest importance, and it is true that technology has greatly affected the process of retrieval, but the idea of utility of retrieval has always been included with the idea of classification.

\section{Technology and LIS}

Although it is true that technology has changed everything including libraries and library services, but it is not true to say that the library and information science are equal to information technology. Yes, if the theoretical basis for this discipline is o.k., then technology serves this field along with other disciplines. Almost all disciplines have been affected and developed by technology.

Thus, if there is not enough theoretical and systematic basis for the discipline then technology may harm instead being helpful. Bloomfield (2001) states that nowadays, using internet is a problem. He says "difficulties in using the Internet, as a searching device, can be frustrating" Then he clarifies that "the problem seems to be the lack of a theoretical foundation for the art of indexing". Therefore, if we look at this discipline in a right way then technology does its best. Indexing which is the main anxiety for retrieval may improve if the theoretical observance gets its way.

\section{Meta Science and Information Studies}

Before stating new proposal, it is worth noting two things:

\section{A: Relationship and Classification/Organization of Knowledge}

Relationship, mostly affiliated with knowledge, is a subject which attracted the views of many librarians and information scientists. Many specialists found that in library and information science the notion of relationship is of high importance. Beans and Green (2001), state that the number of relationships has increased up to 120 among which three (hierarchy, associative, and partative) are most important (Svenonious, 2000). Hjorland (2002) indicates: "information need is attached with the notion of relationship". This may be what Bean \& Green (2001) mean when they say that, after entity, there is nothing but relationship. Relationships exist everywhere; as we combine entities to form more complex entities, as we compare entities, as we group entities, and so forth. Indeed, any thing that we might initially regard as a basic and elemental phenomenon is wrapped with internal and external relationships. Relationship is an association among two or more entities or among two or more classes of entities. Svenonious states (2000):

The relationships expressed by subject languages are of three general types: hierarchical, synonymy and near relatedness. The first two of these and to some extent the third, 
derive from the meaning relationships found in natural -language dictionaries or lexicons. Nearly all definitions in a natural -language dictionary reference hierarchical relationships of the genes- species type. Since Aristotle's time these have formed the backbone of definition. Nearly all indicate sameness in meaning, in the form of synonymy relationships as well as relationships between terms with overlapping meanings. Thesauri and classifications build on these, but often go beyond them to include relationships that are syntagmatic or extra lexical, unlike lexical or definitional relationships, which are wholly pragmatic or a priori; syntagmatic relationships are contingent or empirical. The former expresses tautological relationships among ideas; the latter expresses relationship knowledge about the real world.

As relationship exist in all we see or touch in oral world it is preset in written document and object. One must consider that relationship is not limited only to the relevance between documents and users as it is usually practiced by information specialists these days. In broad sense the relationship among terms in vertical and horizontal phases to clarify the semantic characteristic of the words is of high importance. One who acts as knowledge specialists not only searches for the best scientific classification in comparative studies, but looks forward to serve the users through better indexing.

\section{B: Social attribution}

Although many subject specialists discussed on knowledge presentation and management tacitly confirm the convergence between library \& information science, nearly all of them could not get rid of this idea that LIS has its root in social application. Budd describing Jesse Shera's view as a socialist of knowledge indicates that he is still in the mood of users and social application. His passage, very similar to the field of communication, is as follows (Fadaie, 2004a):

Jesse Shera's view in his article Jesse Shera, Socialist of Knowledge states that his aim was to bring about a unity of subject, vehicle, and object by librarianship. The subject in Shera's opinion, Budd says, is the user, while the vehicle is the bibliographical record and the object is the content of records. In another passage he mentions that in Jesse Shera's view information agencies are involved in a kind of trinity- or: a) the atomistic which means technology of operation, b) content which means what is transmitted, and c) context which means social environment in which the whole action take place.

Even Bakhtin considers LIS theory through communication and dialogism (Budd, 2001).

Taking into view the above mentioned considerations I would like to argue that the name of librarianship, especially in Persian language which is called Ketabdari, which at first glance means having books, does not convey the exact expected meaning of this discipline in its new concept which was described. More over, it does not fit with the new term of information science or services. I would rather to propose a title such as Meta sciences and information studies. Some has proposed in Iran Ketabshenasi (universalogy) before (Ebrami, 1379/2000). It is worthy to be stated, as mentioned before, that this discipline is derived from the very basic need of man for retrieval of information: retrieval one's thought, one's ordinary tacit or explicit knowledge up to one's theoretical sciences appeared in the form of papers, books, or other documents. The creation of libraries, and information centers, individual or public, is due to the fact of man's need for information/knowledge retrieval. It is clear that the library is one of the main places which manifests from this idea.

\section{The New Definition}

So if we consider the above mentioned points and the new name as MSI, or MSIS (Meta Science and Information Studies) and try to find out a new definition for it, it may be as follows: 
It is a discipline that deals with concise recognition of knowledge (classification) and considers the cross relationships (vertical \& horizontal) among the scientific and technical terms in order to maintain the exact and fast retrieval of information and knowledge.

As a definition, according to traditional logic must be comprehensive and restrictive, there fore, in the above definition, the word concise it excludes the detailed explanation of knowledge as for the history and philosophy of knowledge as well as the pure philosophy. These two disciplines may discuss the information and knowledge in full detail; as what they are and how they were treated in the past. Cross relationship among the scientific and technical terms excludes the Linguistics and Communication, but partially includes the semantics, because the cross relationship among terms need Semantics. The word special excludes the common terms such as ordinary, folklore and slang words. And the phrase exact and fast retrieval includes the information and knowledge management, information seeking behavior, information economics, bibliometrics and partially information technology and services (IT\&IS).

This new approach which I called it as Meta science and information studies (MSI) is a discipline which discusses the classification / indexing of knowledge and its relationships among all scientific terms, vertically and horizontally, and explores and explains the semantic relationships among terms to benefit users in retrieval (Fadaie, 2005). Therefore the problems of this discipline are to find out the most suitable classification scheme of knowledge for retrieval which defines these relationships in a way that facilitates the communication between users and documents. All common and sophisticated people live with the idea of classification and retrieval, then, the library as a distinguished tool appears and stands significant to serve people. By this definition the relationship of information studies is stronger to Meta sciences than librarianship. Because one who recognizes knowledge can find to which discipline a piece of information belongs. According to this definition this new defined discipline gets its root from Philosophy, not Social sciences such as Communication or Education and so on. In fact, any classification scheme for knowledge representation must be backed with a philosophy, or a theoretical basis. Dewy Decimal classification has some portion of philosophy while Library of Congress classification scheme has no theoretical basis. The new scheme of library classification called Universal Binary classification with two principles of binary and hierarchy is supposed to be completely backed with philosophy (Fadaie, 2004b).

If one argues that this new definition may have some overlaps with the philosophy or philosophy of science, the answer, as I mentioned before is that the philosophy discusses the mere existence and the philosophy of science goes through the historical aspect of knowledge and science. While this discipline considers the classification schemes and compares them and tries to find and refine the relationships among terms in such a way that the users, in library or out if it, can retrieve their information needs. Libraries, private or public, are the main manifestation of this discipline, because they actually collect any kind of documents which represent knowledge. Hjorland (2002) states that the information needs relate to the quality of existed knowledge and the skill of the users. Table 1 may have it more: 
Table1. The different characteristics between present situation and proposed one

\begin{tabular}{|c|c|c|c|}
\hline No. & Characteristics/situation & Present situation & Proposed situation \\
\hline 1 & Name & $\begin{array}{l}\text { Library \& information } \\
\text { sciences (LIS) }\end{array}$ & $\begin{array}{l}\text { Meta sciences \&information } \\
\text { studies (MSI) }\end{array}$ \\
\hline 2 & Theoretical basis & $\begin{array}{l}\text { Unknown/ library or } \\
\text { books? }\end{array}$ & $\begin{array}{l}\text { Man's need for information } \\
\text { and knowledge (Retrieval) }\end{array}$ \\
\hline 3 & Identity & Vague/taken from library & $\begin{array}{l}\text { knowledge classifica- } \\
\text { tion/organization and retrieval }\end{array}$ \\
\hline 4 & Definition & $\begin{array}{l}\text { Comprise of Social ser- } \\
\text { vices }\end{array}$ & $\begin{array}{l}\text { Comparative study of schemes } \\
\text { through classification \& re- } \\
\text { trieval }\end{array}$ \\
\hline 5 & Upper class & $\begin{array}{l}\text { Social science/ Educa- } \\
\text { tion/or so }\end{array}$ & Philosophy \\
\hline 6 & $\begin{array}{l}\text { Relationship between li- } \\
\text { brary \& information Sci- } \\
\text { ences }\end{array}$ & Not clear & $\begin{array}{l}\text { Clear/ may be as genus, spe- } \\
\text { cies }\end{array}$ \\
\hline 7 & Originated from & Library & $\begin{array}{l}\text { Natural human need for re- } \\
\text { trieval }\end{array}$ \\
\hline 8 & Direct users & $\begin{array}{l}\text { Librarians/ Information } \\
\text { specialists }\end{array}$ & $\begin{array}{l}\text { All scientists esp. libraries \& } \\
\text { information centers }\end{array}$ \\
\hline 9 & Relationship/relevance & $\begin{array}{l}\text { Between document \& } \\
\text { user }\end{array}$ & $\begin{array}{l}\text { Among all subjects and sub- } \\
\text { subjects/users }\end{array}$ \\
\hline 10 & Library & Is creator of LIS & $\begin{array}{l}\text { Is created by MSI \& library is } \\
\text { its main representation }\end{array}$ \\
\hline
\end{tabular}

\section{Conclusion}

As already mentioned, the library and information disciplines, although very important, suffers from the lack of theoretical basis. The author believes that this is because they derived its concept from a wrong place. That is, in the industrial age, when they encountered with the huge collection of books and other documents, instead of finding a theoretical basis for this new science and services they tried to answer the thirsty users who were waiting to receive their information needs. They hastily searched for some classification schemes such as DDC and LCC, and some trained people to take the job. Then they thought that it was the library as a building of collection that created this discipline, while the creation of library was due to the fact of man's needs of information. In other words, before the establishment of library as a formal place, there has been the necessity to find and retrieve the information and knowledge gathered and obtained before, individually or socially.

Therefore, the librarianship which is actually the science of science, or the recognition of knowledge itself briefly, is more explained and exposed by the term of Meta Science or the like, and it is more related with the concept of information studies. Now, this new defined discipline belongs to the upper class under the philosophy, rather than sociology, communication or education. Recently we observe that many subject specialists, in search of theoretical basis for LIS, found their way on knowledge presentation and management. They clearly mention that this discipline is very much related to knowledge recognition and presentation. They argue that the relationship between classification and knowledge may be like the two sides of the same coin. 
Finally I would like to remind that one may agree with this proposal totally or partly. That is changing the name may satisfy somebody in English spoken nations or in other nationalities. Also one may disregard the naming but agree with the new definition partly or totally.

\section{Acknowledgement}

I appreciate the effort of Mr. Nader Naghshineh for his kind editing of the paper.

\section{References}

Bean, C., \& Green, R. (2001). Relationships in organization of knowledge. London: Kluwer.

Bloomfield, M. (2001). Indexing-neglected and poorly understood. Cataloging and Classification Quarterly, 35(1).

Budd, J. M. (1998). An epistemological foundation for library \& information science. Library Quarterly, 65(3).

Budd, J. M. (2001). Information seeking in theory and practice; Rethinking public services in libraries. Reference \& User Services Quarterly, 40(3).

Christ, J. M. (1365/1986). Mabani-y- ketabdari (The foundations of librarianship...). (Asad allah Azad, Trans.). Mashad, Astan Quds, Razavi,.

Fadaie, A. G. (2004a). A dynamic look towards classification and retrieval. Cataloging and Classification Quarterly, 38(1).

Fadaie, A. G. (2004b). New scheme for library classification. Cataloging and Classification Quarterly, $38(2)$.

Fadaie, A. G. (2005). User satisfaction through better indexing. Cataloging and Classification Quarterly, 40(2).

Ebrami, H. (1379/2000). Shenakhti az Danesh shenasi (Epistemology for knowledgeology).Tehran: Ketabdar.

Ellis, D., Allen, D., \& Wilson, T. (1381/2002). Information science and information systems. (R. Fattahi, Trans into Persian). Tehran: National Library of Iran.

Hynek, J. (2002). Document classification in a digital library. Technical Report no. DCSE/TR 2002-04 40. Retrieved from http://www.kiv.zcu.cz/publications/2002/tr-2002-04.pdf

Hjorland, B. (1381/2002). Bunyad hay... (Library \& Information Science: Practice,) (Assd allh Azad, Trans). Tehran, IR. National Library.

Hirland, B. (2005). Library and information science and the philosophy of science. Journal of Documentation, 61(1), 5-10.

Hjorland, B., \& Albrechtsen, H. (1381/2002) Be suye ... (Toward a new horizon in information science domain-analysis) (Naheed Tabatabaee, Trans.) Tehran, National Library.

Kawsnik, B. H. (1999). The role of classification of knowledge representation and discovery. In: EBSCohost; Library Trends, 48(1).

Losee, R. M. (1990). The science of information: Measurement and applications. N.Y.: Academic Press.

Maltby, A. (1975). Sayer's manual of classification for librarians (5th ed.). Great Britain: Andre Deutsch/Agrafton.

Miksa, F. L. (1992). The concept of the universe of knowledge and the purpose of LIS classification. In N.J. Williamson \& M. Hudon (Eds.), Classification Research for Knowledge Representation and Organization, Proceeding of the $5^{\text {th }}$ International Study Conference on Classification Research. Canada, 1991. London: Elsevier, pp. 89-100. 
Mukohreji, A. K. (n.d.). The history and philosophy of librarianship. (Assad allh Azad, Translated into Persian). Mashhad: Astan Qods Razavi.

Muller, R. J. (n.d.). Building class models in UML. Retrieved from http://Librarybooks24x7.com/viewer.asp?bookid=936\&chukid=088844124

Reigeluth, C. M. (n.d.). Module 3: Concept classification. Retrieved from http://www.indiana.edu/ idtheory/methods/m3b.html

Svenonious, A. (2000) The intellectual foundation of knowledge organization. London: MIT Press.

Thompson, J. (1977). A history of the principles of librarianship. Clive Bigley \& Linnet Books

Wilson, T. D. (2002). Curriculum and catastrophe: Change in professional education. Journal of Education for Library and Information Science, 43(4), 296-304.

Yoder, A. R. (2003). The Cyborg librarian as interface: Interpreting postmodern discourse on knowledge construction, validation, and navigation within academic libraries. Libraries and the Academy, 3(3).

\section{Biography}

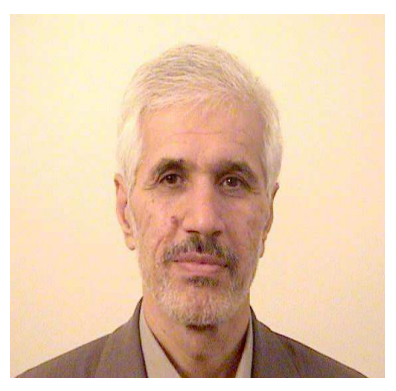

Gholamreza Fadaie, Ph.D in LIS is associate professor in Faculty of Psychology \& Education, University of Tehran. Iran. He is 62 years old and has about 14 books and more than 30 articles in Persian. Also he has several articles in English and Arabic. Four of his English articles have been published in Cataloging and Classification Quarterly journal in 2004 and 2005. He has some new idea about classification and philosophy of LIS. 